\title{
The Discovery of an American Brig: Fieldwork Involving Applied Remote Viewing Including a Comparison with Electronic Remote Sensing
}

\author{
Stephan A. Schwartz \\ Randall J. De MatteI
}

The Mobius Society

Submitted February 21, 2019; Accepted December 29, 2019, Published March 31, 2020

https://doi.org/10.31275/2020/1481

Creative Commons License CCB YD C

1988 Parapsychological Association Conference presentation, "The Discovery of an American Brig: Fieldwork Involving Applied Archaeological Remote Viewing."

1989 Conference on Underwater Archaeology/Society of Historic Archaeology Annual Meetings presentation, "The Discovery of an American Brig: Fieldwork Involving Applied Archaeological Remote Viewing, Including a Comparison with Electronic Remote Sensing."

\begin{abstract}
In the fall of 1987, Mobius, under a license from the Bahamian Government, carried out an archaeological survey of an area of the Grand Bahama Banks encompassing some 579.15 square miles (1500 sq. $\mathrm{km}$ ). This was done with a 125 [foot research vessel, Seaview, and its ten $\square$ ders. This was the continuation of a line of research utilizing nonlocal consciousness to locate and describe archaeological sites, both marine and terrestrial, in countries all over the world, using a Mobius $\mathrm{a}$ esigned consensus and concept analysis protocol. Part of the protocol calls for a parallel electronic remote sensing survey, as well as historical research, to see whether the location of a site had been previously recorded. This is a line of research dating back over a decade and published in a series of papers. And this was carried out. This report compares the results of that Bahama Bank survey employing the Mobius consensus concept analysis remote viewing protocol, comparing it with electronic remote sensing, visual search, and historical survey. To illustrate the protocol, this report focuses specifically on the most significant of several sites located, the wreck of a previously undiscovered armed American merchantman be lieved to be the brig Leander. Under the Command of Captain William Johnson, she sank for unknown reasons near Beaks Cay on April 6, 1834,
\end{abstract}


while returning from Manzanilla, Cuba, to her homeport in Boston, Massachusetts. This report describes how she was consensually located and found in a subsection of the License Area known as Consensus Zone C; an area of $11.81 \mathrm{sq}$. miles ( $30.59 \mathrm{sq} . \mathrm{km}$ ) of water. The data show that the nonlocally sourced information using remote viewing led to the sitels location, and that electronic remote sensing was not useful. It should be noted that this is consistent with all prior Mobius expeditionary projects. In every instance nonlocally sourced information accomplished what electronic remote sensing could not. In addition to location information, a total of 193 descriptive concepts describing what would be found at the site were proffered by twelve remote viewers. Of these, 148 concepts, or $75 \%$ of the total, could be evaluated through direct field observations, or historical research. An evaluation of this material reveals $84 \%$ corn rect, $12 \%$ partially correct but usable, and $4 \%$ incorrect. There is little accuracy variation across the sequence of material from the Los Angeles interviews ( $84 \%$ correct, $13 \%$ partially correct but useable, and 3\% incorn rect), to the data proffered during interviews in Florida where Seaview was moored, or onEli te nonlocally derived data acquired once Seaview was on the Bahamas Banks ( $81 \%$ correct, $11 \%$ partially correct but use able, and $8 \%$ incorrect). Approximately 300 notable wrecks went down, not just in the License Area but across the entire Banks, from 1500 to $1876 \mathrm{CE}$ as determined by a thorough search of historical records and archival material in the U.S., the U.K., Spain, and the Bahamas. To make a conservative assessment of this location occurring by chance, assume the wrecks are evenly distributed not throughout the Banks, but only within the License Area. That said, we should expect to see 6.12 boats in Consensus Zone C $(11.81 / 579.15 \times 300=6.12)$. The brig site is 5,000 square $\mathrm{ft}$. (464.5 sq. $\mathrm{m}$ ), equaling 0.00018 of a square mile. Within Consensus Zone C, 65,849 sites of this size could be placed, thus yield ing a grid of 65,849 cells. If the probability of selecting this particular cell in the grid by chance exceeds $p \geq 0.05$, then remote viewing can be considered a determinative factor. The probability of finding this one 5,000 Bq . Ift. area is then $6.12 / 65,849=p 0.00009$, which strongly sug $\square$ gests that chance is not an explanation for the locating of the Leander.

Keywords: remote viewing; electronic remote sensing; Grand Bahama Banks; Leander; Beaks Cay; remote viewers; shipwreck

\section{BACKGROUND AND OVERVIEW}

In the fall of 1987, Mobius, under a license from the Bahamian Government, carried out an archaeological survey of an area of the Grand Bahama Banks encompassing some 579.15 square miles $(1,500$ 


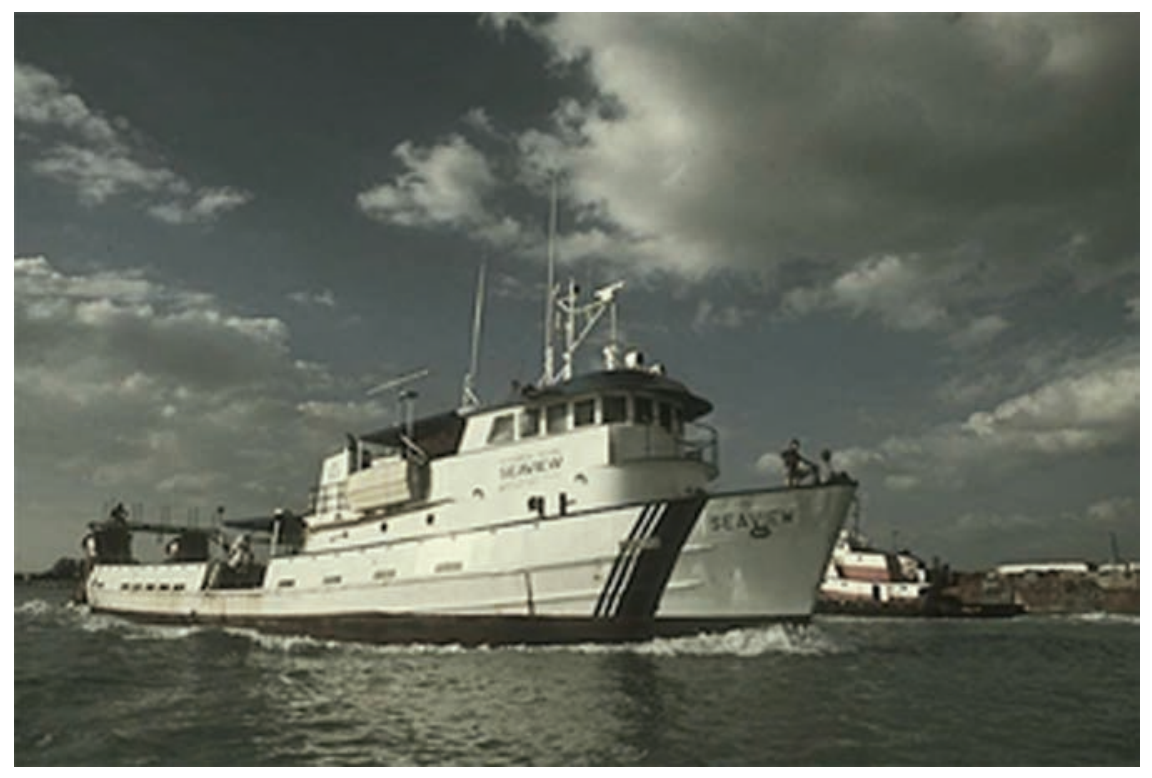

Figure 1. The Research Vessel Seaview.

sq. $\mathrm{km}$ ). This was done with the 125 foot research vessel Seaview (Figure 1 ) and its tenders. This expedition was the continuation of a line of research utilizing nonlocal consciousness to locate and describe archaeological sites, both marine and terrestrial in countries all over the world, using a Mobiusd esigned consensus and concept analysis protocol (Schwartz, 1980a, 1980b, 1980c, 1985; Schwartz et al., 1984; Schwartz \& De Mattei, 1987). Part of the protocol calls for a parallel electronic remote sensing survey, as well as historical research, to see whether the location of a site had been previously recorded, and this is reported as well.

This is a line of research begun in 1968 which shows that even though we may not possess a universally accepted explanatory model for remote viewing (Jahn, 1982), the accumulation of research argues that this approach offers an efficient, costl ffective procedure for locating and finding sites, both marine and terrestrial, particularly those deeply buried and obscure to visual inspection.

This paper covers the location and excavation of an unusually intact shipwreck, believed to be the American brig Leander, which was 
located through remote viewing, and excavated during the course of three voyages of the research vessel Seaview (Figure 1).

The work in this report was carried out by a team of parapsychologists, archaeologists, geophysicists, and historians under the auspices of the Mobius Society, in conjunction with Seaview Exploration Associates, under license from the Bahamian Government. It describes a total of four weeks of field time devoted to this site, involving 443 hours of dive time by an archaeological dive team composed of 18 men and women working from Seaview, as well as a team of historical and archival researchers working in the U.S., Spain, Great Britain, and the Bahamas. Several sites were found in the Beaks Cay area using this approach; this site was selected for this report based on five considerations: 1) The site most clearly illustrates the relative strengths and weaknesses of various search techniques; 2) It contains the most well|preserved ship remains in the area; 3) We have been able to locate the historical documentation concerning the probable identity of this wreck, thus allowing the most comprehensive evaluation of the remote viewing data; 4) This area has been covered by an unusually clear Landsat 4 computer image with very minimal cloud coverage; and, 5) A comprehensive magnetometer survey for this site was carried out.

\section{HISTORICAL CONTEXT \\ THE GULF STREAM AND THE GRAND BAHAMA BANKS}

The Gulf Stream was discovered by the Spanish in the mid[50os. For three and a half centuries, until steam replaced sail and emancipation brought about the collapse of the slavelpowered, sugarcane economies of the Caribbean Islands, it remained the best way back to Europe from much of the New World (Figure 2).

This extraordinary oceanographic phenomenon, which Matthew Fontaine Maury called $\mathrm{t}$ he River in the Ocean $\mathrm{C}(1855)$, passes between Florida and the Bahamas, channeled on the west by the Florida Keys and on the east by the vast shallows of the Bahama Banks. The Banks back to historical times have been described as the Grand Bahama Banks to the south and the Little Bahama Banks to the north. Both are composed of calcareous limestone thousands of feet deep, formed 


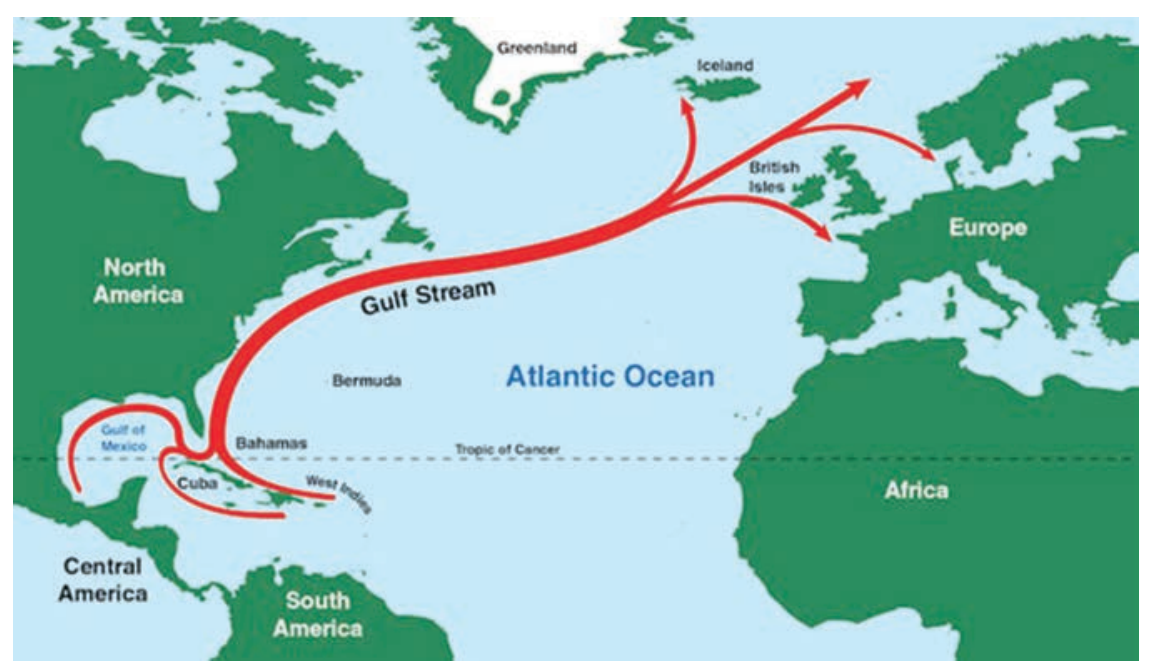

Figure 2. The Gulf Stream.

from the action of organic matter on the light sand. This rocky plateau is covered with 5 to 15 feet $(1.52 \square 4.57 \mathrm{~m})$ of sand fringed on its western side by a long series of reefs, rocks, and cays. The average water depth over the Banks is about 15 feet $(4.57 \mathrm{~m})$ until it reaches its western edge, whereupon there is a precipitous dropoff to more than 800 feet $(244 \mathrm{~m})$. Visually from a ship, however, this difference is not readily perceptible, which accounts for the large numbers of ships that have been lost on the Banks.

Vessels blown eastward out of the deep Gulf Stream by storms, particularly hurricanes, were driven across the flats until they either struck a sandy area shallow enough to ground them or a submerged reef knocked out their bottoms. Added to the hurricanes and storms was piracy.

The new governments that grew up as the Spanish empire fell apart at the end of the Napoleonic Wars were corrupt, poor, and rebellious. For them piracy of ships from more developed nations was an attractive activity, and by 1821 a good part of the United States Navy was in the Caribbean suppressing pirates (Tuchman, 1987). Before the struggle against piracy was over, more than 500 American vessels were captured by pirates in the Caribbean (Goldenberg, 1976). In the years 1812 to 1815 alone, more than 3,000 assaults occurred (Goldenberg, 
1976). England and France helped, but even in 1829, the year before the death of Simon De Bolivar, the Maine Enquirer advised: DAll vessels bound to the Spanish Islands to be armed at least with one or two guns, a dozen muskets and boarding pikes or harpoons ... (Maine Enquirer, 1829). In the time period of particular interest for this report, issues of weather may have been further complicated by the piracy that plagued the Caribbean. Both are possible critical factors explaining why the Leander was found where she was.

There are no absolute figures on the number of vessels of all sizes lost on the Banks, but the best approximation is to be found in the database compiled by MobiusDarchival research team. It suggests that, from the $15^{\text {th }}$ century onward, approximately 300 notable, i.e. mentioned in historical sources, vessels met such a fate, with the loss of ships, cargo, lives, or all three (Schwartz et al., 1988).

The north coast of Cuba was a particularly rank nest of semidegal and illegal pirates and privateers. If one wanted to avoid the notorious Cuban coast, it was possible to go north across the Bahama Banks in order to come out in the northपflowing Gulf Stream somewhere due east of what is now Miami. The passage between Beaks Cay and Browns Rock is one of the last safe exits from the Banks, through the barrier reefs into the northward[flowing Gulf Stream. It was here that an armed American brig sank. Ship measurements, analysis of wood, pottery, and metal objects recovered from the wreckage, as well as historical research, make a compelling case that the wreck is the Leander (Baker, 1973; Edye, 1832). She was under the Command of Captain William Johnson when she sank for unknown reasons near Beaks Cay on April 6, 1834, while returning from Manzanilla, Cuba, to her homeport in Boston, Massachusetts (Baker, 1973).

\section{PERSONNEL}

There were six categories of personnel, organized as teams, involved in this project:

1. The Parapsychology \& Management Team. Mobius Chairman and Research Director Stephan A. Schwartz was the Project Director of the research covered in this report. Mobius Executive Director Randall J. De Mattei was Deputy Project Director. 
2. The Remote Viewers. Twelve men and women acted as remote viewers in this experiment. The viewers were blind to everything except their own interview session. Eight of the viewers took part in the project through direct in person interviews. Four responded to mailed questionnaires. For eight of them, through earlier research, we have profiles from the Personality Assessment System (PAS) (Winne \& Gittinger, 1973).

\section{a. In-person interview remote viewers:}

Andre Vaillancourt, RП: a man, 36, musician and film producer. He is defined by PAS as an IRU6. RW had never been to the Grand Bahama Banks.

John Oligny, RL: a man, 37, staff photographer for a major Western daily newspaper. He is defined by PAS as an IFA8. RL had never been to the Grand Bahama Banks.

Ben Moses, R־3: a man, 40, feature film producer and documentarian. He is defined by PAS as an EFU6. R $B$ had never been to the Grand Bahama Banks.

Hella Hammid, Rप4: a woman, 64, fine arts photographer, defined under PAS as an ERA8. RTh had never been to the Grand Bahama Banks.

Judith Orloff, Rg: a woman, 36, boardb ertified psychiatrist. She is defined under PAS as an IFU3. RG had never been to the Grand Bahama Banks.

Alan Vaughan, RG: a man, 48, author, psychic, lecturer, and parapsychological researcher. RE \& research work has primarily been in dreams and precognition. As a respondent, he has participated in studies for many research groups. He is defined by PAS as an IRU2. RG had never been to the Grand Bahama Banks.

Rosalyn Bruyere, R8: a woman, 36, director of a healing outreach clinic. She is defined by PAS as an ERU6. R8 had never been to the Grand Bahama Banks.

Michael Crichton, RП5: a man, 44, author, feature film director. He is defined by PAS as IRU6. RП 5 had been to Nassau in the Bahamas, but never to the Banks. 


\section{b. Remote viewers by mail:}

Keith Harary, RF : a man, psychologist, parapsychologist. PAS profile not available. R耳 had never been to the Grand Bahama Banks.

Umberto Di Grazia, Rg : Italian television consultant. Rg had never been to the Grand Bahama Banks.

Terry Ross, RПo: a man, retired investment broker. PAS profile not available. Rho had never been the Grand Bahama Banks.

Roger Nelson, RП7: a man, psychologist and parapsychologist. PAS profile not available. R[7 has never been the Grand Bahama Banks.

The R $\mathrm{Rnumbers} 11,12,13,14$, and 16 were assigned, but for a variety of reasons the individuals to whom these numbers were assigned did not end up being interviewed.

The 12 individuals who did participate were selected on the basis of their past performance in other archaeological remote viewing experiments. They volunteered approximately two hours of their time for the interviews, for which they received no fee. Five of themB th,

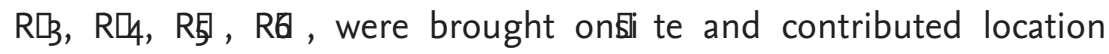
material on the site that is included in this paper.

3. The Archaeology \& Archivist Team. Peter Throckmorton of Nova University, one of the founders of modern nautical archaeology, was the Archaeological Director, and he oversaw all archaeological aspects of the project. A recognized authority on wooden sailing ships, Throckmorton is a member of the Society of Professional Archaeologists and the author of numerous scholarly papers, books, and articles on nautical archaeology. In addition to his role in interpreting what was brought up during the fieldwork phase of the project, Throckmorton coordinated the archivists and historians who carried out the historical archival research and did the archival work in the Bahamas himself. The other members of this team were: Catherine Throckmorton in Maine, working on colonial newspaper searches with a particular emphasis on Massachusetts shipping; Richard Swete, at the Mariners $\square$ Museum in Newport News, Virginia, working in colonial newspaper and academic literature searches with a particular emphasis on southeastern colonial and U.S. shipping; Stephen Rogers in London and Greenwich, working in the British Admiralty records, and 
searching period European papers; and Michel Parret in Seville, working in Spanish commercial and shipping records. The database that was developed as the fruit of this work is the first comprehensive survey of these waters (Schwartz et al., 1988).

4. The Geophysical \& Electronic Remote Sensing Team. Saul Friedman, formerly of Lamont Geological Laboratories, and Robert Bisson, Chief Executive Officer and Senior Researcher for BCl Geonetics, carried out the electronic remote sensing aspect of the project. Friedman did the on Eli te proton precession magnetometer survey, while Bisson coordinated an aerial survey and satellite surveillance analysis of the site.

5. The Divers \& Ships Personnel. Fieldwork was carried out by teams of certified divers who also were part of the crew of the Seaview.

6. Photography, Audio Recording, \& Videotape Team. A photographic record was made by a number of divers as events unfolded. Additionally, a professional videotape crew came out to Seaview to make a realt ime video record of the remote viewers at work.

\section{ELECTRONIC REMOTE SENSING}

Aerial Survey. Prior to the Seaview arriving on station, three overflights were made at an altitude of $100 \square 200$ feet above the ocean surface. Flight speed on all three occasions was approximately 50 miles per hour. By flying spaced, parallel, northDsouth patterns, a thorough coverage of the entire license zone was possible. Photographs were taken on each flight.

Satellite. A Landsat 4 image, commissioned under a National Science Foundation Grant, taken on May 3, 1983, was obtained. The image covered the northern part of the license area, bounded by

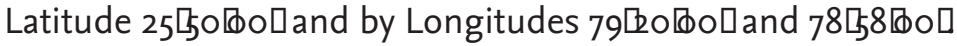

Magnetometer. A Barringer SML23 Shallow Marine Proton Precession Magnetometer System, Console S/N 750, Sensor S/N 8046, was obtained from the Barringer Corporation. The instrument was checked by the manufacturer prior to shipping and again upon receipt aboard the Seaview. The instrument was run at 1.01 econd interval pulse cycles from a diesel[powered small craft. The sensor was towed 140 feet from the craft and performed within manufacturerls tolerances in the 
daily test runs that were carried out before actual survey procedures were implemented. Magnetometers principally locate ferrous mass (no signal is produced by wood or non[ferrous metals).

The Seaview magnetometer procedure was to conduct parallel runs approximately 30 feet apart. Lanes were usually run northblo uth, with perpendicular eastDwest lanes run across the same area when anomalies were recorded.

Navigation. The great challenge in nautical search procedures is fixing a location in such a way that it can be reliably relocated. The Seaview was equipped with a Foruno Satellite Communications navigation downlink, model FSN50, linked to a Forun LCG o Lorand .

Because the Lorand signal is weak on the Banks, electronic navigation is notoriously unreliable over long periods. Variations as much as 0.3 of a mile $(.48 \mathrm{~km})$ can occur over several days. For this reason, we established, through repeated readings off the SatCom, a fixed known point. The Loran was corrected daily by the SatCom relative to this point, thus assuring reasonable accuracy standards. A Raytheon Model R41 rastar scan radar equipped with range and bearing capability provided the ability to fix small boat locations. Sextant fixes were also shot, as needed, from the magnetometer craft on land masses (Beaks Cay, Brownl Cay) in the northernmost consensus zone. Most important, however, was the use of simple styrofoam buoys. These were dropped with $8 \mathrm{Dl} 6$ pounds of lead at the end of the line at every significant magnetometer $\mathrm{Bi}$ t

Metal Detectors. Dive teams making a visual inspection of a site were equipped with metal detectors, Whites model P1 hooo. Unlike the magnetometer, these metal detectors are nond iscriminating; that is, they detect the presence of any type of metal within their range. Tests were run to establish an efficacy parameter: Under optimal conditions, a metal object the size of a dinner spoon could be detected under three feet of sand. As expected, larger objects produced stronger signals.

Visual Inspection. Two divers at a time were slowly towed over significant portions of the license area in water 8018 feet (2.449. $.49 \mathrm{~m}$ ) deep. They were visually inspecting the bottom, which was typically sand with eelgrass. 


\section{ARCHIVAL RESEARCH}

\section{Maps}

In August 1985, we began our research, seeking to define, on the basis of historical research, an area where there was some likelihood that shipwrecks existed, representing the maritime history of the Caribbean. This archival work produced an area
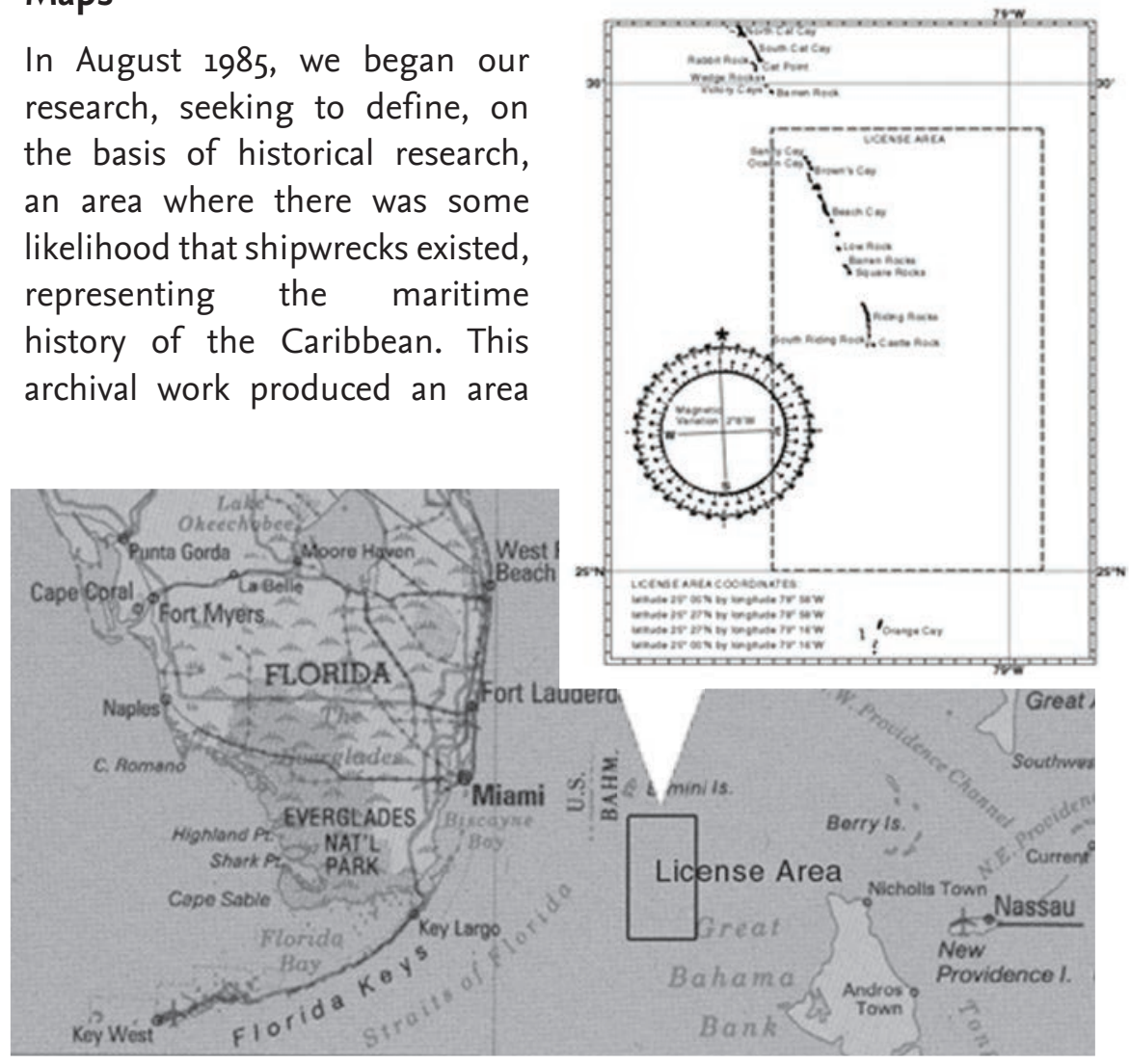

Chart 1. The License Area.

approximately 579.15 square miles (1,500 sq. $\mathrm{km})$ in size. Once we had defined this general area we applied for and received an exclusive license from the Bahamian Government to search it (see Chart 1). The next task of the Archival Team was to produce the first compendium of all known shipwrecks from 1500 to 1876 known to have gone down on the Banks@n area much larger than the License Area. 1876 was established as the cutoff date for this database because ships after that date usually have little or no historical significance. The database had a second function. It allowed us to develop a baseline with which to develop a statistical analysis. 


\section{REMOTE VIEWING}

While the License Area was only a small portion of the Bahamian national waters, it was still an area so large that it was obvious from the beginning that the remote viewing portion of the project would have to be carried out in stages. We started with a map of sufficient scale to encompass the License Area, and used the Bahamian Government Hydrographic Chart (BLSH702, scale 1:300,000). This work began in December 1985 (see Chart 1). Consistent with the protocol and our earlier work, a new remote viewing session map was used with each viewer. To prepare the map, significant place names and other geographic data were removed, a compass rose was added, and the map was transferred to a Mylar $\square$ master. Identical blueprint copies were run off, thus eliminating colors that might cause unconscious cueing. These blueprint charts were then used one at a time in a series of individual interview sessions with the twelve remote viewers.

\section{Consensus Zones}

When all sessions from the first cycle of onet ob ne interviews were completed, the maps were then oneby日 ne put on a light table covered by another blank copy of the map, and the location data were transferred to what became the Composite Master (see Chart 2). This process revealed locations that were consensually selected. Where more than one remote viewer selected the same area, the aggregate area encompassed by their collective marks was designated a Consensus Zone (see Chart 2). In this way, the entire search area was reduced to three major and several secondary Consensus Zones. It was this composite with its Consensus Zones which laid the foundation of the location hypotheses, and that led to the second cycle of remote viewing sessions that would direct the fieldwork.

More detailed charts of the three major Consensus Areas were then obtained. The Northernmost Consensus Zone, which is the subject of this report, was covered by a Bahamian Government Chart (Bimini Sheet 8, Ref: PU822070, scale 1:10,000) (see Chart 3). Note the difference in scale. The maps used in this second set of interviews were prepared in the same way as those used in the first sessions. Then, following the same protocol, a second set of interviews was carried out. 


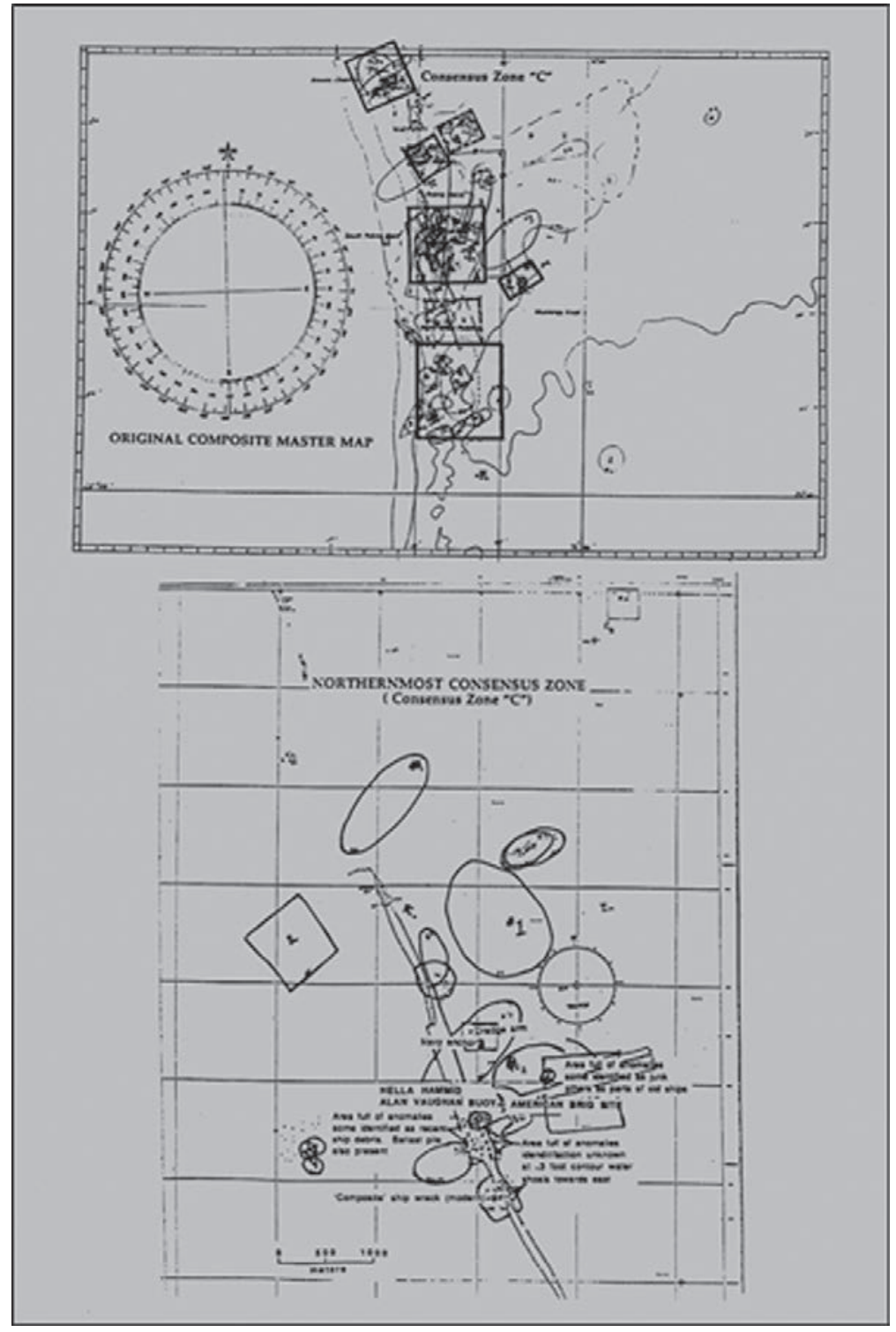

Charts $2 \&$ 3. The Composite Master, at the top, was produced by transferring the data from individual remote viewers $\mathrm{C}$ charts to a single master. Each square encompasses areas where multiple selections of the same area have been made. Note Consensus Zone C. The lower map is just Consensus Area $\mathrm{C}$, the site addressed by this report. Other wrecks and debris were found in the Consensus Zone and in other areas, too. 


\section{Remote Viewing Sessions}

Via Mail Sessions. Remote viewers were blind to all but their own session. As already noted, some of the individual sessions in both the first and second cycles of the map probe phrase were done via mail. These viewers received the map and a series of questions, each in its own sealed, numbered envelope. The questions they contained were answered sequentially, with each envelope remaining sealed until the viewer felt the previous question had been responded to as fully as possible. Responses included audio tapes, drawings of things to be found at the sites marked on the map, and the map itself with the viewerls locations. Each sheet of paper, signed and dated, as well as the audio tape, were then returned by mail.

InB erson Sessions. Where interviews were conducted in person, the interviews were split between the authors to eliminate any subtle biases that might develop in the researchers and lead them to unintentionally cue the viewers. It was not a question of cueing a correct answer, since that was unknown to all, but of creating a kind of Bo ise $\mathrm{l}$ a favored outcome, that would override the nonlocal awareness perceptions. There was no discussion between interviewers; thus, each interviewer was blind to the interviews he did not conduct until all sessions had been completed.

Everyone throughout the experiment, of course, was blind as to whether the information proffered by either electronic remote sensing or remote viewing was accurate until the answer was revealed through fieldwork.

Interview Room. A room was equipped with a table on which were an audio taperecorder, a lavolier microphone, and the specially prepared map; pencils and pens; a file folder containing the initial charge or direction; and blank $8.5 \times 11$ inch paper for drawing RV images.

Interview Steps. Following are the steps in a standard interview:

1) Remote viewer enters. On the table, face down, is the map.

2) The tapetrecorder is turned on and the tape is initialized with the names of the interviewer, the names of the remote viewers, the time and date of the interview, and the interview location.

3) The initial task instruction for the session is given. With slight variations, the task charge was: $\mathbb{W}$ he $n$ you feel comfortable doing 
so, please turn over the map. Would you please go over it however you like and locate any shipwrecks you discern? Please make a circle or shape around the location site on the map, making it as small as you can. $\square$ Some people just move their hand slowly over the map, some use a pendulum, some just stare carefully across the map.

4) After the locations are made and sometimes while they are being made, a spontaneous conversation goes on. The interviewer will point at a location asking, $\mathbb{B}$ ou are at the site, you are lifelli ze, what do you perceive? The role of the interviewer is to elicit, without cueing, further impressions concerning that location.

5) In the course of the session a remote viewer may be asked to or may want to make drawings to illustrate perceived images. These drawings, when completed, are signed and dated by the viewer. They are numbered sequentially beginning from \#1.

6) When the remote viewer feels he or she has exhausted the sense impressions available, the session ends (a time ranging from 20 minutes to an hour). The map is signed and dated by the viewer and the interviewer. Map, tape(s), and drawings are all coded with the date and remote viewerls number and filed for subsequent analysis. The session is concluded.

We go into some detail about this procedure because it is our view that what is going on in all remote viewing is a transaction involving everyone defined by intention and agreement as being part of the experiment. We are in essence faced with an engineering problem in which a nonlocal circuit made up of all participants is created by intention. Studies in the life sciences suggest, to us at least, that levels of interaction whose mechanisms are unknown at presentalt hough well bserved(G $\mathrm{Gad}$ et al., 1961; Nash, 1982; Kreiger, 1974; Justa Smith, 1971) $\square$ have to be considered in designing these experiments. Practically, this means that what everyone feels, thinks, and holds focused intention on is a factor in the protocol.

\section{REMOTE VIEWING ANALYSIS: LABORATORY \& APPLIED}

In laboratory remote viewing experiments, it is possible to establish a fixed number of variables in the form of a descriptor list, in which

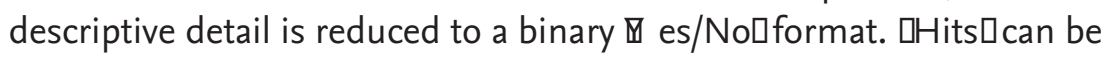




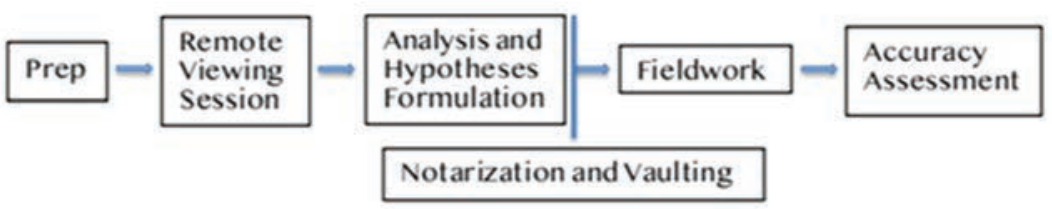

Figure 3. Creating an unimpeachable chronology.

described in terms of whether or not a given descriptor is turned on or off, and the descriptions provided by remote viewing can be measured against a previously encoded correct answer form created by visually examining the target (Jahn et al., 1980). In this way statistical analyses can be developed.

In an archaeological project such as this one, the circumstances of the experiment are very different. The target is a large geographical area in which viewers first select specific locations and then describe in detail what will be found at that location. After multiple viewers have gone through this sequence, choosing the locations and a concept byE oncept analysis are carried out. Thus, remote viewing creates the hypotheses that guide the fieldwork.

\section{Unimpeachable Chronology}

From a research perspective, the key to an experiment like this is that it must have an unimpeachable chronology. The sequence of events has to be absolutely clear and documented for any unassailable assessment of nonlocally derived information to be achieved. In this way an unimpeachable chronology is established.

All of these preffieldwork data, and their analysis, are then notarized and turned over to an independent third party, thus creating an unimpeachable chronology (see Figure 3).

\section{Archival Research}

The archival research was important because through that research it could be established what was and was not known about the nonlocally sourced location and description data at a site. Only fieldwork can say whether a given bit of nonlocal data is correct or not. The experiments are truly tripleblind. Also thanks to the exhaustive survey by the Archival Team, 
we have a baseline against which to measure the probability of a given location; it is one in which we can repose with reasonable confidence.

The central difference between a laboratory experiment and an applied experiment is that in the laboratory experiment the point of the study is a statistical probability outcome. In an applied experiment, the sourcing of nonlocal information through the remote viewing protocol is only a midway point, useful, as with all remote sensing input, in making decisions as to how to conduct fieldwork. Only fieldwork and post fieldwork conceptbyDconcept expert assessment can establish accuracy.

To do this assessment requires the considered expertise of several disciplines. It is a far more granular process than the coarse Iscreen $\square$ of a descriptor list, typically limited to 20 or 30 discrete concepts. The process is described in detail below.

\section{FIELDWORK PROCEDURE}

Fieldwork begins by determining whether there were any historical records of sites within the Consensus Zones. This is followed by studying the satellite imagery for each Consensus Zone to determine whether the locations in the Consensus Zone could have been established through aerial surveillance. This is followed by a twol tep process:

\section{Electronic Remote Sensing}

The magnetometer (mag) survey team goes first, carrying out its electric remote sensing search within a Consensus Zone. In addition to its search gear, the tender is equipped with a radar reflector, a twolway radio, and a number of buoys (Figure 4). The tender is manned by a geologist specializing in electronic remote sensing and a tender operator (who occasionally performed both roles). After this independent survey is completed and the data are logged, the remote viewer phase begins. If a remote viewing $\mathrm{Bi} \mathrm{t} \mathrm{C}$ is reported, the mag tender follows behind the

viewerdi rected tender, and relmags the area selected by the viewer to see if the location could be picked up now that the remote viewers had pinpointed it. In this way it is possible to know with certainty whether a site had been located by magnetometer or by remote viewing, or both. 


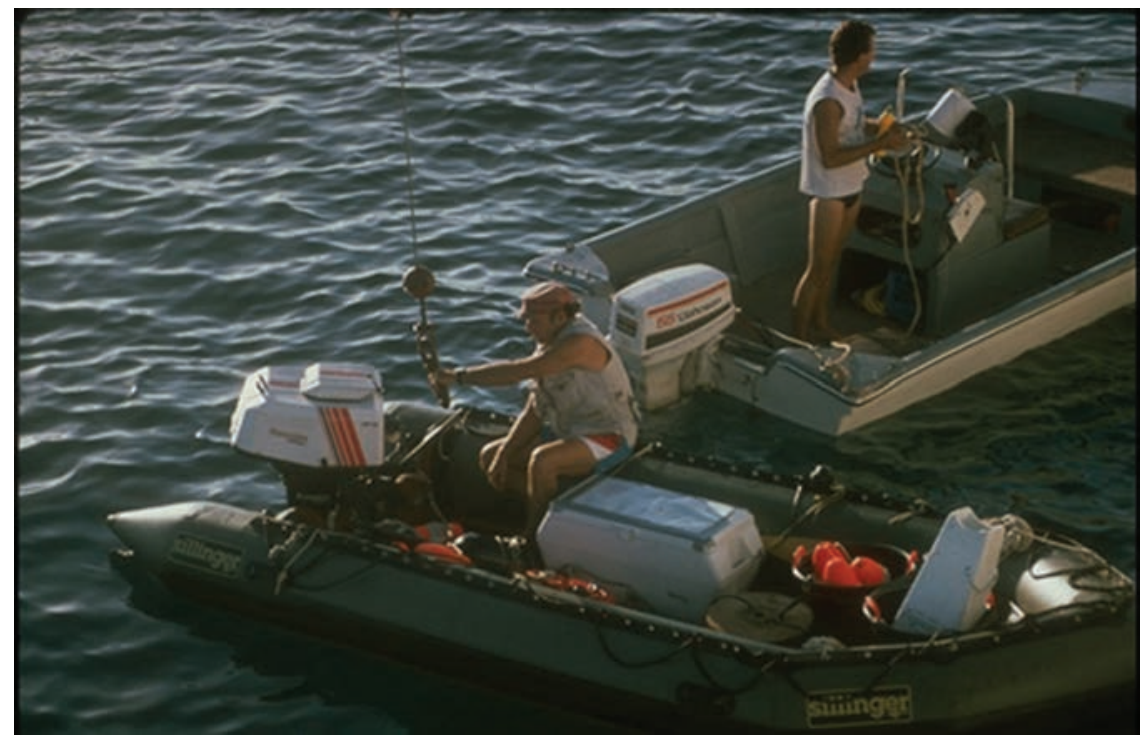

Figure 4. The electronic remote survey tender preparing to launch. To protect it from the sea, the magnetometer is in the white chest. Note also the buoys.

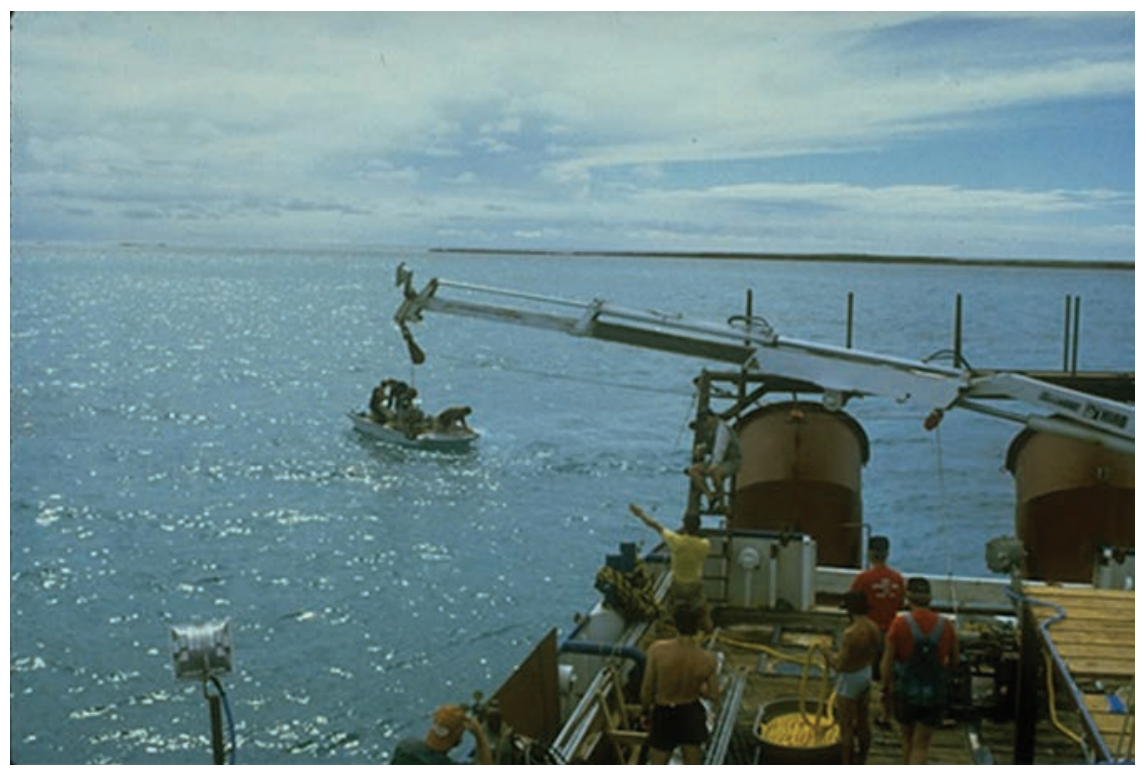

Figure 5. A tender with a remote reviewer launches from the Seaview to locate the site. 


\section{Remote Viewing}

In the open ocean, in the license area, remote viewers come out to the Seaview one or two at a time (see Figure 5). When they are aboard, the ship moves to a selected Consensus Zone. The viewers are individually taken in one of Seaviewls tenders carrying a diver operator, a researcher/ diver, and the viewer. Each boat is equipped with a VHF twoLway radio and a radar reflector. The reflector allows the position of the tender to be fixed relative to the known location of the Seaview. The tenders go to different outer boundaries of one of the Consensus Zones developed during the pre[fieldwork phase. Once at the boundary the viewers are given a numbered styrofoam buoy and asked to guide the tender to the location of the wreck they had previously located during the Map Phase. The remote viewer moves the tender across the sea to a location of their choice. The numbered buoy is dropped. The Seaview is contacted, and the tenderls location is fixed and logged on the 1:10,000 chart for that area (see Chart 3).

\section{RESULTS: ELECTRONIC SENSING \& VISUAL SURVEYS}

Satellite. The Landsat image for this location is unusually fine. There was virtually no cloud cover, and penetration to the bottom was clear and unequivocal. In these waters, however, resolution of unclassified satellite imagery was not adequate to locate or identify sites as small as the wreck site reported here, so this form of electronic remote sensing was not useful.

Magnetometer. The magnetometer survey over this site (see Figure 6) never produced readings greater than 60 gammas, insufficient to justify archaeological excavation. Subsequent excavation explained why magnetometers did not detect the ship. The target ship was an unusually fine one built with the leading technology of its age. The shipl fastenings were brass, bronze, or Muntz metal (a patented brass $\square$ based amalgam introduced in the early part of the $19^{\text {th }}$ century). The mass of ferrous metal, which is the magnetometerls target, was far smaller than would have been found on a ship of less expensive or earlier construction. It should be noted that this failure of electronic remote sensing to locate the site has been previously reported in every applied 


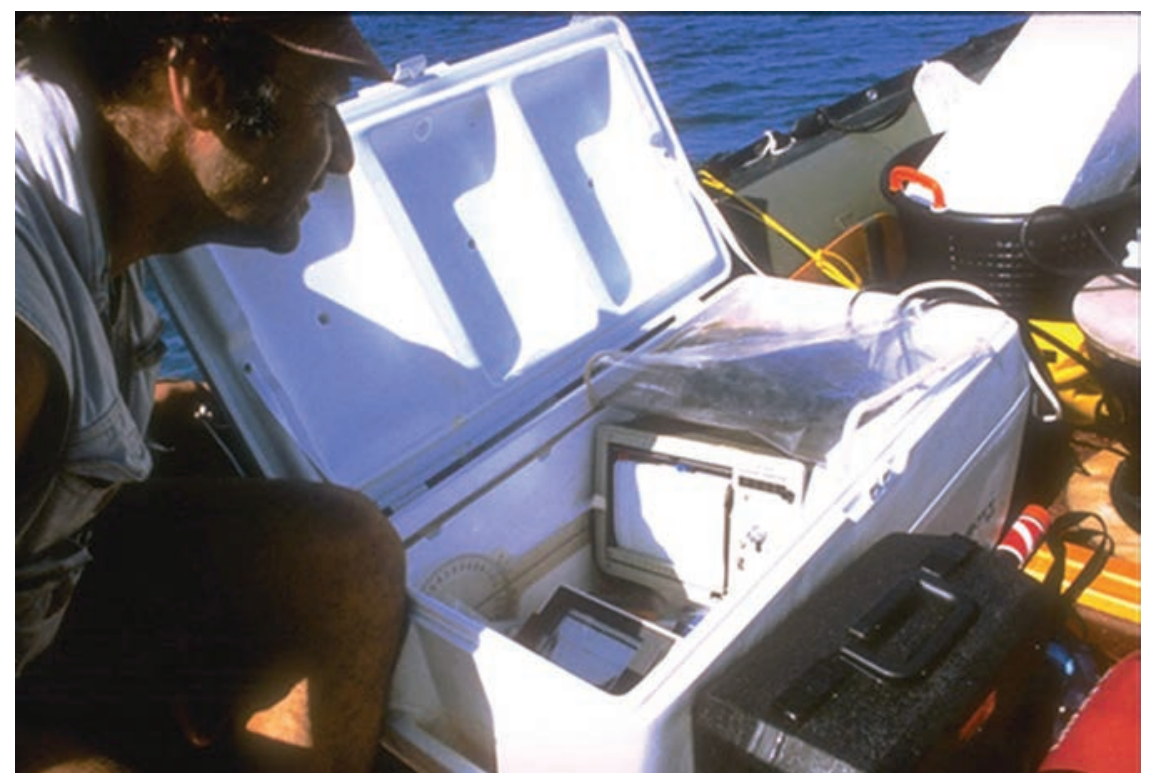

Figure 6. The magnetometer both on the Seaview and from the tender were unable to locate the wreck site.

archaeological project done before this one. The data have repeatedly shown that the nonlocally sourced information using remote viewing led to a sitels location, and that electronic remote sensing was not useful. In every instance nonlocally sourced information accomplished what electronic remote sensing could not.

Aerial. Three flights were carried out, at different times of day, and with different cloud covers, to assure complete visual aerial surveillance. No shipwrecks, not already on the charts, were visible. There was no sign of the wreck site that is the focus of this report.

Visual. Salvagers from the 16th century onward have been searching this area particularly because it is immediately adjacent to Brownls channel. There are no reports of such a discovery. This is also a favored area for sport divers, and at least two sport dive operations regularly bring out clients for dives working the Beaks Cay area. Interviews with their staffs established they had no previous knowledge of the site (Bottom Time, no date). 


\section{RESULTS: REMOTE VIEWING}

Location. As the Master Composite Map for Consensus Zone C (see Chart 3) shows, this wreck was found by remote viewing at the location predicted. On September 29, 1987, Hammid and Vaughan were taken out in one of the tenders and within an hour had agreed on a site and dropped a buoy. Through this stepd own process, a search area that began with 579.15 square miles $(1,500 \mathrm{sq} . \mathrm{km})$ depicted on a map thousands of miles away was reduced to an exact location from a tender at sea, as is required if such information is to be really useful.

When we found the site on September 29, 1987, we were unequipped to do excavation, and after fixing the location we left the buoys and went into dry dock where alterations and additions were made to the Seaview. When we returned to the area some three weeks later, no remote viewer was aboard. Steering on the previously logged Loran readings, we sought the buoys for finet uning the location. The buoys left on the earlier voyage had been blown away by storms or stolen by fishermen.

We could not be sure about the Loran beyond saying that we were within 500 yards $(457 \mathrm{~m})$ of where we had found the shipwreck. No remote viewers were present. Three days of towing divers and redoing the magnetometer survey of the Consensus Zone within those 500 yards failed to relocate the site, demonstrating how difficult it is to locate a site using traditional visual and electronic remote sensing even when you know its location down to a few hundred yards.

Three weeks later we returned to the Consensus Zone for a third time, this time with a remote viewer on board. Using the nonlocally sourced data the viewer provided, we positioned ourselves. By then it was too dark to make a visual inspection. The next morning divers went down to look at what at first appeared to be a typical low rise of white sand covered with eel grass (Figure 7).

Even with the remote viewing guidance, the divers could find nothing, until as the dive was ending one of them saw a particular coral that seemed unnaturally symmetrical (see Figure 8). He tagged it and drew it to the attention of the other divers who agreed it seemed odd. On a $\mathrm{Gu}$ nch $\mathrm{l}$ the diver struck the coral with his dive knife, and a piece gave way. The chip revealed what was later determined to be a bronze keel bolt. This led to a reexamination of some small rocks, later 


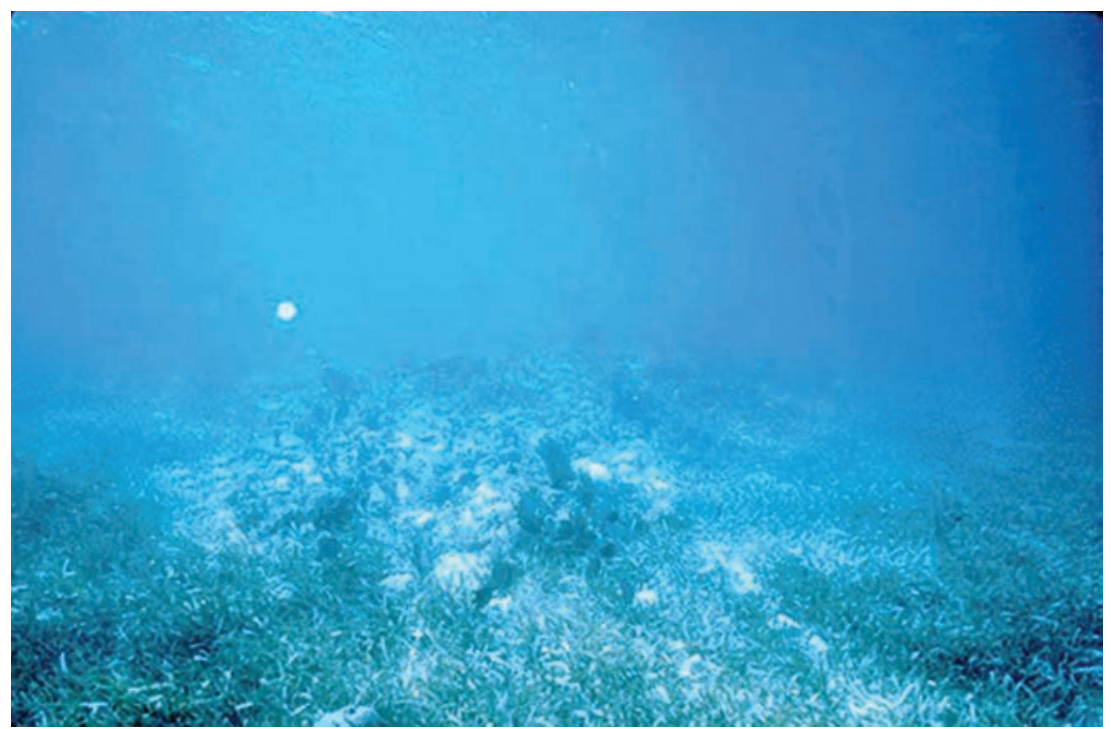

Figure 7. The site as it appeared on the first dive. Nothing to see. No magnetometer hit that would suggest anything was there to be found.

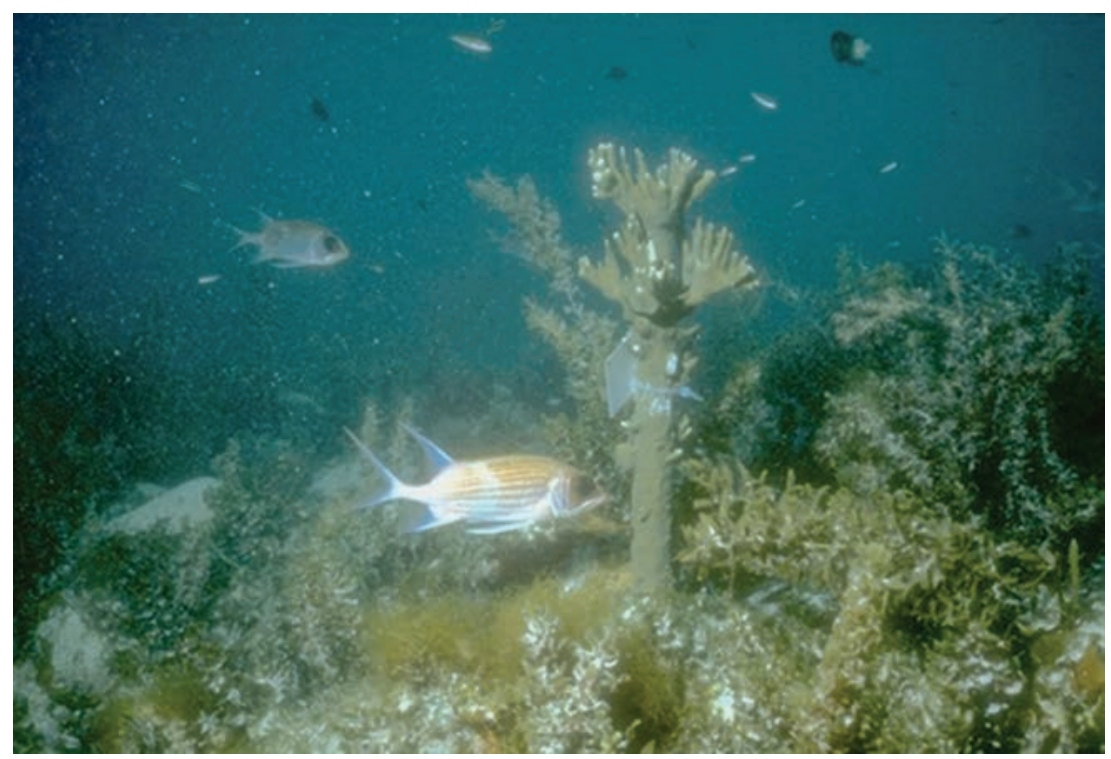

Figure 8. To a diver, this slightly symmetrical coral stood out, and he tagged it, brought it to the attention of the other divers, who agreed, and stuck in his dive knife revealing a bronze keel bolt. 


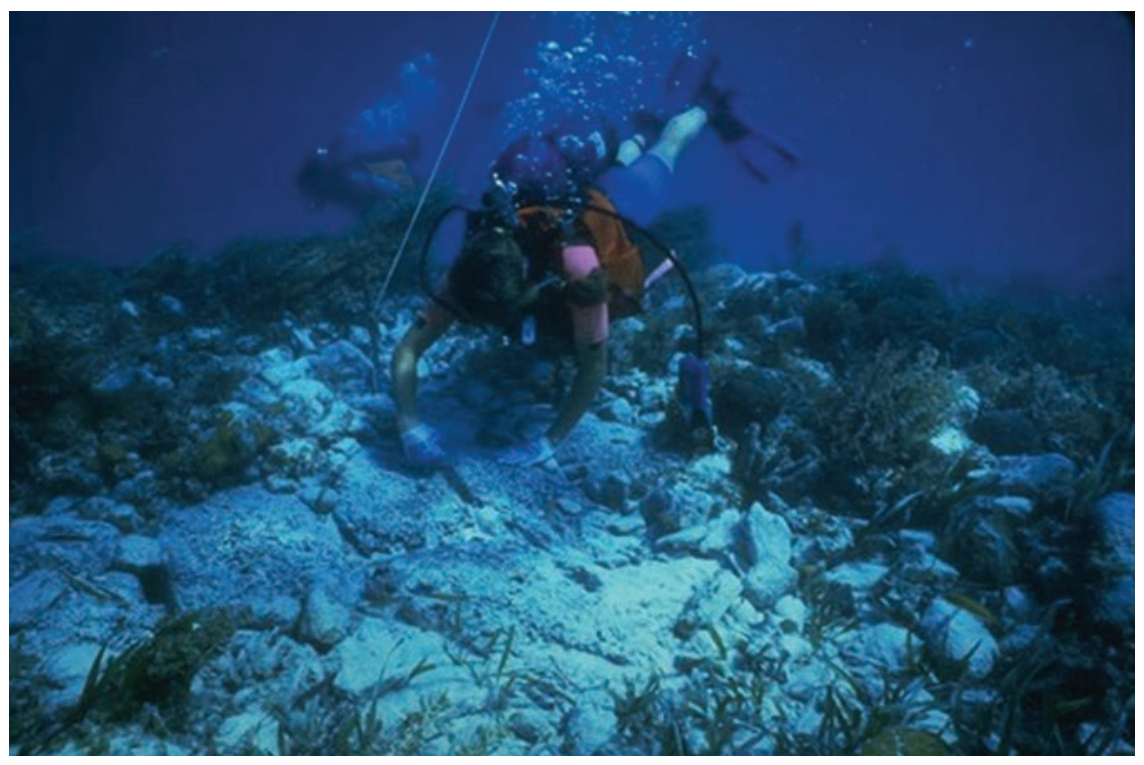

Figure 9. The site was staked and a buoy line was tied to it to guide the tenders, while divers explored the site.

determined to be ballast stones. This entire process took perhaps five hours.

After a second failure of mag and visual survey in an area of only a few hundred yards, the site had been relocated by remote viewing (see Figure 9), and excavation began immediately. It revealed an unusually intact wreck buried three to five feet beneath the eel grass and sand. Nothing was visible except the fire corall overed keel bolt and some ballast stones mixed in with the indigenous rocks. Only excavation revealed that hidden beneath the sand, coral, and rocks was the remains of a collapsed American armed merchant brig which sank within the early decades of the 19th century. It also showed that the buoy dropped by Vaughan and Hammid was less than 35 feet from the keel bolt, and directly on top of the wreck, as excavation would reveal.

Descriptive Concepts. The transcripts of the interview sessions show there were 193 conceptual concepts put forward about this site by the remote viewers. This material covered surface geography, sub $\square$ surface geology, ship location, the position and identity of the ship, and detailed descriptions of its component parts and contents. Based 
TABLE 1

Concept Accuracy Evaluation

\begin{tabular}{|c|c|c|c|c|c|}
\hline & Correct & $\begin{array}{l}\text { Partially } \\
\text { Correct }\end{array}$ & Incorrect & $\begin{array}{c}\text { Nond } \\
\text { Evaluable } \\
(\mathrm{NO})\end{array}$ & Total \\
\hline \multicolumn{6}{|l|}{ PreBi eldwork } \\
\hline Total number of concepts & 91 & 14 & 3 & 38 & $146 / 108$ \\
\hline Percentages including $\mathrm{Na}$ & $62 \%$ & $10 \%$ & $2 \%$ & $26 \%$ & \\
\hline Percentages minus $\mathrm{N}$ 目 & $84 \%$ & $13 \%$ & $3 \%$ & $\mathrm{Q}$ & \\
\hline \multicolumn{6}{|l|}{ Ons ite } \\
\hline Total number of concepts & 30 & 4 & 3 & 10 & $47 / 37$ \\
\hline Percentages including $\mathrm{Na}$ & $64 \%$ & $9 \%$ & $6 \%$ & $21 \%$ & \\
\hline Percentages minus $\mathrm{Nl}$ & $81 \%$ & $11 \%$ & $8 \%$ & $\square$ & \\
\hline \multicolumn{6}{|l|}{ Combined } \\
\hline Total number of concepts & 121 & 18 & 6 & 48 & $193 / 145$ \\
\hline Percentages including $\mathrm{NB}$ & $63 \%$ & $9 \%$ & $3 \%$ & $25 \%$ & \\
\hline Percentages minus $\mathrm{NE}$ & $83 \%$ & $12 \%$ & $4 \%$ & $\mathrm{Q}$ & \\
\hline
\end{tabular}

on archaeological fieldwork and archival research, the accuracy of the concepts was determined (see Table 1).

A Piori Evaluation. The reconstructive material is subject to what might be called The Generic Criticism. That is: When a remote viewer is asked to describe something in or under the sea, there is a generic sort of description that many presume will cover many, if not most, wrecks. In the sense of naming or drawing certain nautical universals, for instance an anchor, this is true. But in most respects, as we have learned by more than a decade of direct field experience and study of the literature, this criticism is true in only the broadest terms. Shipwrecks present themselves in many ways. There are thousands of boat types. The reality is that beyond a few generalities, sunken wrecks, the condition they are in, and the things in the wreck all are specific to that wreck.

In this case the remote viewers described a ship that was intact. Several said it sank in place. This sounds generic, but, in fact, the brig 


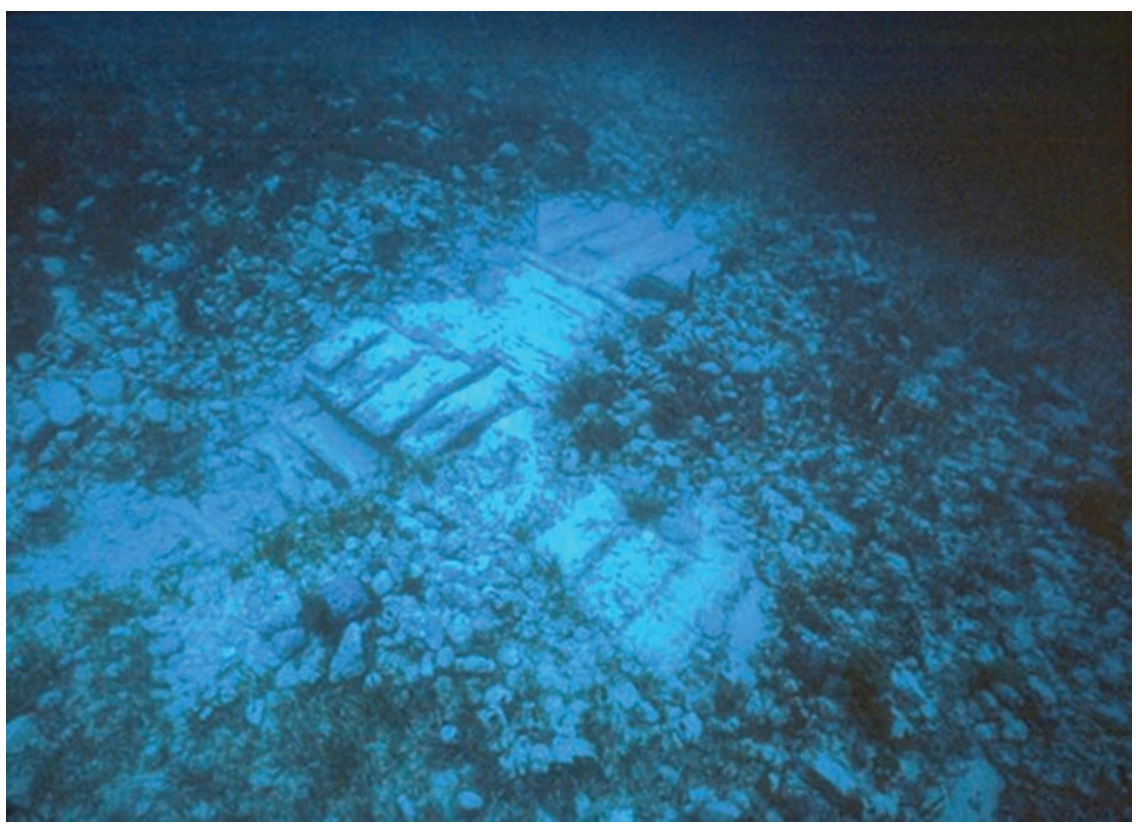

Figure 10. The timbers of the brig Leander represent a rare case on the Bahamas Banks of a shipwreck that is still intact. This is because the Leander probably sank while at anchor. The remote viewing description of timber stacked like $\mathrm{G}$ ailroad ties $\square$ was completely validated by the fieldwork.

is the only wooden sailing shipwreck ever found in the area this intact. Sailing ships driven or misklai led onto the Banks did not often stay completely together like this one when they sank. Typically, one finds a debris trail along which, over some distance, a ship breaks up, spilling its contents and losing parts of its structure. So the description of an intact ship was quite meaningful, and one of the reasons we chose to do an extensive excavation. Here, at an even smaller scale, are several other examples of remote viewing, with a low a priori probability of being correct, that excavation later demonstrated were, in fact, correct. Rh 5 described the site by saying: $\square$ feel wood, big pieces of wood, like railroad ties ... . (see Figure 10). This may sound generic. It is not. The massive timbers of the Leander present the rare case of a ship that sank intact. There is no other ship recovery on record in the License Area that matches this site. Expanding the scale, there does not seem to have been 
another equivalent reported excavation like this on the entire Banks.

Similarly reported was land small glass bottles. S Small glass bottles rarely survive the constant movement of sand and currents on the Bank. The probability of discovering one intact is very small. Yet two were found as described in the wreckage of this site (see Figure 11).

Or, $\mathrm{C}$. . pewter ... I dont know what it is, but some kind of corroded metal $\square$ (see Figure 12); and, Bve ryday artifacts. . . Again, these observations only seem commonplace. Based on other excavation

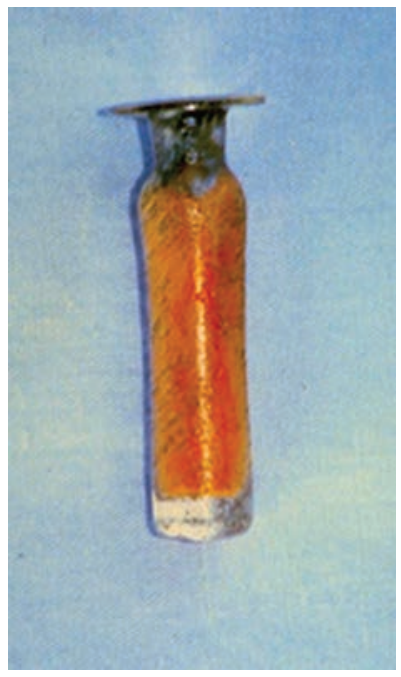
reports, the site is notable for the number

Figure 11. Remote viewing predicted that Dsmall glass bottles $\square$ would be found, and they were.

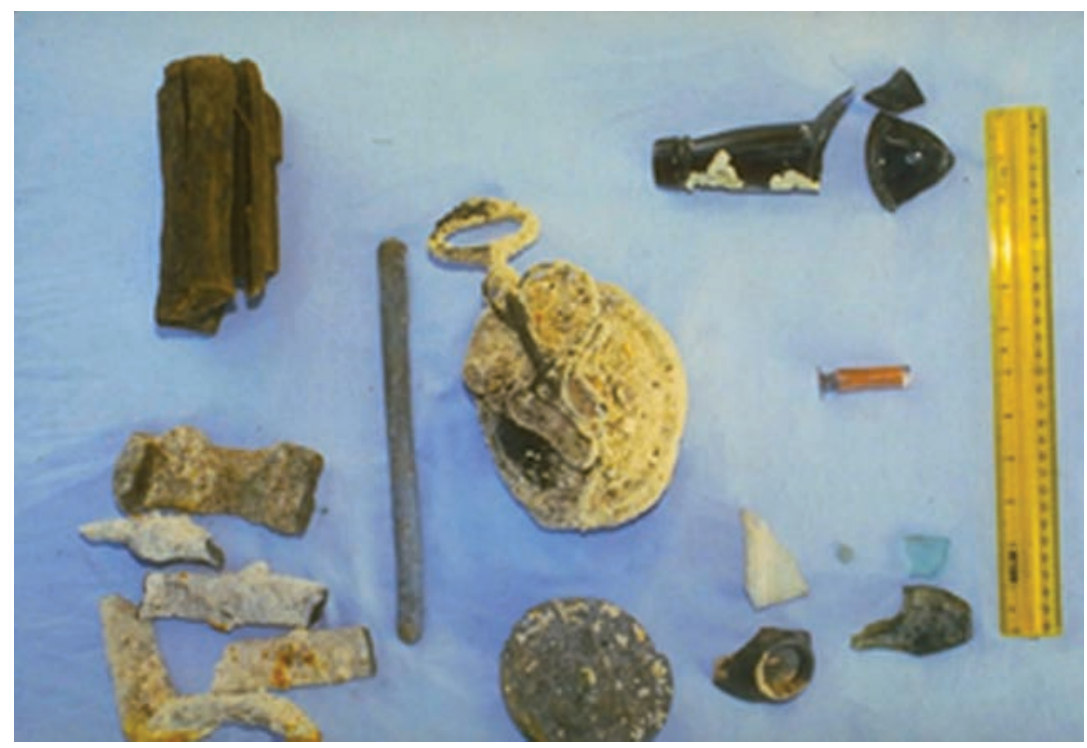

Figure 12. Remnants of containers. Of particular interest is the pewter cruet in the center; it had been predicted through remote viewing. 
of such items that have survived. Among the artifacts recovered: the Captain!s pearlthandled razor, parts of a drafting set, and a silver or pewter cruet.

Experience taught us that arguments proposing that most wrecks can be described by predictable, interchangeable clich $\square$ images simply do not hold up. Similarly, the criticism that anywhere one looks one is likely to turn up a wreck is ludicrous in the face of the immensity of the ocean, the uniqueness of each site, and the academic and historical search literature.

Statistical Analysis. There are three ways to determine the statistical probability that this discovery was a chance occurrence: 1 ) The location of the site only in reference to Consensus Zone C; 2) The location of the site in reference to the entire License Area; 3 ) the location of the site in reference to the entire Grand Bahama Banks. Let us select only the first two, since it must follow that if these two analyses are above chance, then the third, involving the entire Banks, must be even more improbable.

No matter which case is selected, one begins by recognizing that approximately 300 notable wrecks went down, not just in the License Area but across the entire Banks, from 1500 to 1876 , as determined by a thorough search of historical records and archival material.

Let us take the most conservative (and obviously artificial) posi $\square$ tion: Assume all 300 of those wrecks were within Consensus Zone C. The search area of Consensus Zone $C$ is 30.59 square $\mathrm{km}$ (11.81 sq. miles, 12 sq. miles of sea minus 0.19 sq. miles of land mass). The brig site is 5,000 square feet, equaling 0.000179 of a square mile. Within Consensus Zone C, 65,849 sites of this size could be placed. In essence, then, we have a grid with 65,849 cells. If the probability of selecting that particular cell in the grid by chance exceeds $p 0.05$, then remote viewing can be considered a determinative factor. In fact, it is $300 / 65,849$ or $p 0.005$; a very significant result.

Let us next take the less conservative, and more realistic (although still artificially conservative), case: Assume the wrecks are evenly distributed throughout the entire License Area. That said, we should expect to see $11.81 / 579.15 \times 300=6.12$ boats in Consensus Zone $C$. The probability of finding one in a 5,000 square feet area is then $6.12 / 65,849$ $=$ po.00009, which strongly suggests that chance is not an explanation for the location of the Leander. 


\section{DISCUSSION}

Remote viewing was the one location methodology that produced accurate, useful location data about this site. That conclusion, however, should not overshadow another, which is also notable: the efficiency of remote viewing. From the time we arrived at the edge of Consensus Zone C, a total of approximately five hours of operation time was required to initially make the location.

If the site had been found by the magnetometer, how long would it have taken? The site is 100 feet $(30.5 \mathrm{~m})$ long by 50 feet $(15.3 \mathrm{~m})$ wide. At that time the traditional approach would have been to use a magnetometer to search the overall area. The ship follows Lorand, or some locally set up navigation system, such as Del Norte, with the magnetometer sensor trailing from a ship operating at no more than 6 knots. Parallel lanes no more than 30 feet $(9.14 \mathrm{~m})$ from one another are run, much like a tractor making corn rows. Thus it is possible to compute with considerable accuracy exactly how long a magnetometer survey will require if one first knows the size of the area to be searched.

The total area of the chart given to the remote viewers to search is 12 square nautical miles [a nautical mile $\approx 6000$ feet $(1,829 \mathrm{~m})$ ]; it measures 3 miles by 4 miles. At 6 knots, a standard magging speed, a run 30 feet $(9.14 \mathrm{~m})$ wide and one mile long is optimally covered in ten minutes. To cover one square mile in $30 \square$ foot $(9.14 \square \mathrm{m})$ swaths, then, would require 200 passes.

Thus, in a $\$$ erfect $\square$ plan, the fastest possible survey time for the chart area can be calculated as $10 \times 200 \times 12=24,000$ minutes $/ 60=$ 400 hours. Adding just the most conservative turnaround and setup time between each of these perfect, oneImile runs, say five minutes, would bring the total up to 600 hours. This $\square$ erfect $\square$ plan, of course, fails to take into account any of the realities of navigation, weather, site obstructions, equipment setup and breakdown, currents, or the other myriad factors that actually would have to be considered while working aboard a ship on the open ocean.

A post hoc reexamination of the two magnetometer surveys of the Consensus Zone reaffirmed that over this site the Seaview did not get anything like the pattern associated with a ship; in fact there were but two spikes, both below 60 gammas, nothing that suggested 
a ship to either the archaeological or electronic remote sensing teams. Understanding why this is so takes some sense of field realities; the question of why the magnetometer did not identify the site on not one but two occasions is an important one.

Removing sand under water is a major logistical operation. It forces any field project to establish a threshold beneath which mag 日i ts $\square$ are discarded as not worth following up. It is simply not practically possible to follow up on every magnetometer $\operatorname{Bi}$ t $\mathrm{t}$ particularly in an area like the Banks where, during the 1940s and 1950s, pilots training for strafing and bombing runs littered the sea with thousands of pounds of expended 50 caliber, machinegu $\mathrm{n}$ bullets and unexploded bombs. The second of the two lowlevel hits at this site came from a large, several[footDong, steell lad, unexploded U.S. Navy bomb.

Low Devel individual bi ts $\square$ when isolated, are also of less interest than a pattern consisting of a number of small 10 15 gamma responses with 300 o gamma spikes. Such patterns suggest that a ship, as compared with a single ferrous object, lies beneath the seafloor overburden. Each expedition must, of course, set its own threshold and pattern requirements, but an informal survey of individuals who have worked the Banks suggests that 30 gammas is about the lowest practical limit, and that these really become meaningful only in the context of a pattern. The ship was expensively built of the latest materials for its time. Thus, it used relatively little ferrous metal, and this made a small target for the magnetometer.

It seems to us that it is reasonable to conclude that the involvement of archaeological remote viewing made the search procedure more efficient, cost effective, and faster than would otherwise have been the case. It is hard to explain away sailing up to the site, dropping a buoy within a few feet of a site, and accurately and uniquely describing the wreckls disposition and contents prior to excavation.

The fact that the site was previously unknown is not hard to explain, given the depth at which the wreck was buried, the paucity of visible signs on the seafloor, and the low iron content because of the use of bronze and Muntz metal. Thus, while one cannot absolutely say that the site would never have been found using electronic remote sensing, but the fact that it lay undisturbed for 154 years in one of the most intensely searched areas of the Banks, supports this improbability. Our 
own unsuccessful attempt to relocate the site, even though we knew it was present, until remote viewing relocated it, further suggests this was the critical variable in bringing about our success.

\section{ACKNOWLEDGMENTS}

The authors wish to thank our shipl Master and crew of the Research Vessel Seaview, without whose tireless work this research would never have happened. We also thank the Bahamian Government, particularly the Honorable Philip Bethel, Minister of Transport and Local Government, and his Deputy Mr. Calvin Balfour, for their gracious assistance, and permission to carry out this research. Most significantly of all we thank the 74 men and women whose financial support made this work possible. And to S. P. James Spottiswoode, our thanks for checking our statistical analysis section.

\section{REFERENCES}

Baker, W. A. (1973). A maritime history of Bath, Maine, and the Kennebec River Region (2 vols.). Marine Research Society of Bath.

Bottom Time. (n.d.). Private communications with dive masters and crews of Bottom Time and Bottom Time II.

Goldenberg, J. A. (1976). Shipbuilding in colonial America. University Press of Virginia.

Grad, B., Cadoret, R. J., \& Paul, G. I. (1961). An unorthodox method of treatment on wound healing in mice. International Journal of Parapsychology, 2, 5ロ19.

Edye, J. (1832). Calculations relating to the equipment, displacement, etc., of ships and vessels of war. Hodgson \& Hodgson.

Jahn, R. G. (1982). The persistent paradox of psychic phenomena: An engineering perspective. Proceedings of the IEEE, 70(2), 1360170. https://doi.org/10.1109/ PROC.1982.12260

Jahn, R. G., Dunne, B. J., \& Jahn, E. G. (1980, February). Analytical judging procedure for remote perception experiments. Journal of Parapsychology, 44(3), $207 \square 231$.

Justa Smith, M. (1971). Paranormal effects on enzyme activity. Human Dimension, 1, $12 \mathrm{D} 15$.

Kreiger, D. (1974). Healing by the laying on of hands as a facilitator of biol nergetic change: The response of in vivo human hemoglobin. Psychoenergetic Systems, 1, 121D129.

Maine Enquirer. (1829). Collection of the University of Maine.

Maury, M. F. (1855). The physical geography of the sea. Harper \& Brothers. Samson Low, Son. In Astronomical Observations. 
Nash, C. B. (1982). Psychokinetic control of bacterial growth. In W. G. Roll, R. L. Morris, \& R. A. White (Eds.), Research in parapsychology (pp. 616 4). Scarecrow.

Schwartz, S. A. (1980a, January 11). A preliminary survey of the Eastern Harbor, Alexandria, Egypt. 11 ${ }^{\text {th }}$ Annual Conference on Underwater Archaeology, Albuquerque, NM, United States.

Schwartz, S. A. (1980b, March 10). The use of intuitionally derived data in archaeological fieldwork. Presentation at the Annual Meeting of the Southwestern Anthropological Association / Association for Transpersonal Anthropology.

Schwartz, S. A. (1980c, April 14). The location, reconstruction, and excavation of a Byzantine structure in Marea, Egypt. Presentation at the Annual Meeting of the American Research Center in Egypt, de Young Museum, San Francisco, CA, United States.

Schwartz, S. A. (1984, December 48). Remote viewing: An applicationsl riented perspective for anthropology. Invited Paper, $84^{\text {th }}$ Annual Meeting of the American Anthropology Association, Washington, DC. Proceedings: A Summary of Data and Theories from Parapsychology Relevant to Psychological Anthropology.

Schwartz, S. A., \& De Mattei, R. J. (in conjunction with Roger Smith, Institute for Nautical Archaeology) (1987, August 5). The Caravel report. $12^{\text {th }}$ Conference on Underwater Archaeology / Society of Historic Archaeology 52nd Annual Meeting.

Schwartz, S. A., De Mattei, R. J., \& Schlitz, M. (1984, December 14018). The Pecos Project: Reconstruction of a life in a Southwestern Indian village along the Lower Pecos River though remote viewing, circa $8^{\text {th }}$ century AD. American Anthropology Association 83 $3^{\text {rd }}$ Annual Meeting, 1984, Denver, CO, United States.

Schwartz, S. A., Throckmorton, P., Throckmorton, C., Swete, R., Rogers, S., \& Parret, M. (1988). A survey from historical sources of ships lost on the Grand Bahama Banks 150001876 . Mobius.

Tuchman, B. W. (1987). The first salute: A view of the American Revolution. Knopf.

Watkins, G. K., \& Watkins, A. M. (1971). Possible PK influence on the resuscitation of anesthetized mice. Journal of Parapsychology, 35(4), $257 \square 272$.

Winne, J. F., \& Gittinger, J. W. (1973). An introduction to the Personality Assessment System.JournalofCommunity Psychology, Monograph Supplement,38. https://doi. org/10.1002/1520D6629(197304)1:2<99::AIDDJCOP2290010202>3.0.CO;2DU 